\title{
The Microbiology Quality Analysis of the Waters of Riuapa River and Its Impact on the Environment
}

\author{
Soukotta Elna*, Oszaer Robert, Bokiraya Latuamury \\ Magister Program of Forest Management, Faculty of Agriculture, \\ Pattimura University, Indonesia \\ *Corresponding author
}

\begin{tabular}{|l|}
\hline K e y w o r d s \\
Waeriuapa, Water \\
quality, Pollution, \\
$\begin{array}{l}\text { Environmental } \\
\text { impact }\end{array}$ \\
\hline Article Info \\
\hline $\begin{array}{l}\text { Accepted: } \\
\text { 04 June 2019 } \\
\text { Available Online: } \\
\text { 10 July } 2019\end{array}$
\end{tabular}

\section{Introduction}

Water is a basic need that cannot be separated from human needs. The increasing number of residents with their various activities also affects the amount and quality of clean water. The problem that arises is the process of using and removing water from the daily activities of the community, which become waste water that is, without prior processing, directly discharged/ disposed off into the river and its environment.
The Waeriuapa is the main river in the Wae Riuapa watershed which is widely used for agricultural irrigation, fishery cultivation ponds and domestic needs such as bathing and washing. As a flowing open-water ecosystem, the Riuapa river receives external disposals starting from upstream to downstream in the form of domestic waste, industrial waste, agricultural waste and from natural disasters such as erosion and landslides. The study conducted was to identify water quality by measuring the level of water pollution both in the river stream and on the river banks, specifically its microbiology quality. The results of the RALF analysis indicates the influence of the station location and season towards the levels of Total Coliform and E. coli bacteria in the river water and water wells that exceed the threshold of quality standards affecting the health of the surrounding environment. Changes in land cover on the WaeRiuapa watershed also influences the debit fluctuations in rainwater and dilution of pollutants, thereby reducing the river water quality with a total Coliform level of during wet season an average of 937.6 amount/ 100ml, during the dry season an average of 2,222.7 amount/ 100ml (BM Total Coliform: 3,000 amount/ 100ml), and $E$. coli at an average rainfall of $35.53 \mathrm{amount} / 100 \mathrm{ml}$, during dry season an average of 20.67 amount/ 100ml (BM E. coli: <1 amount / 100ml). 
the river water, affect aquatic biota, and bring widely harm to human life.

The water quality of the river is a qualitative condition that is measured based on certain parameters and through certain methods according to the applicable laws and regulations. The quality of the river water can be determined through physical, chemical and biological parameters that describe the water quality (Asdak, 2010). The indicator used to measure the biological / microbiological quality of the water is in the form of $E$. coli bacteria and Total Coliform.

The water quality analysis is done by measuring the microbiological parameters of the Riuapa river and its impact to the environment through looking at changes in Wae Riuapa watershed's land cover which is the main objective of this study. It is expected that the results of this study can be taken into consideration and as input for the management of the Wae Riuapa watershed in an environmentally friendly development effort and formulating policies towards pollution control, and efforts to maintain and preserve the water quality of the Wae Riuapa watershed.

\section{Materials and Methods}

The study was conducted at the Riuapa River, West Seram district, which is the main river in the WaeRiuapa watershed. The WaeRiuapa watershed research location has a length of \pm $33 \mathrm{~km}$. In this study survey methods, laboratory analysis, and interviewing of respondents are used. The study was conducted by dividing the Riuapa river into 3 segments, namely the up-, middle- and downstream sections, starting from Rambatu village, Inamosol sub-district to Waimital village and Kairatu village at Kairatu subdistrict with 15 water sampling locations, one point at the river and 2 points on the left and right banks of the river and 2 points in dug wells located on the riverbank within a radius of $<200 \mathrm{~m}$ (Figure 1). Determination of sampling station (segment) is done through Purposive sampling method. Sampling: 2x replications was carried out, namely in the rain and dry seasons. The division of segments and sampling points are based on land use patterns, intensity of community activities and distance from the river - while taking ease of access, cost and time into account (Table 3). The water samples analysis was carried out at the laboratory of the Center for Environmental Health Techniques, Maluku Province. The water quality evaluation refers to PP No. 82 year 2001 regarding class II water quality standards (Table 1), and Permenkes No. 32 year 2017 concerning water quality standards for sanitation (Table 2). The results of the water quality evaluation are associated with the land use in the WaeRiuapa watershed area and community activities around it- this is done through overlaying the research location map with the WaeRiuapa Watershed Land Use Map, and direct observation in the field. Statistical analysis to identify the impact of river water quality on environmental factors using the Factorial Design in Complete Random (RALF) with the following formula:

Yijkl $=\mu+\mathrm{Si}+\mathrm{Bj}+\mathrm{Mk}+\mathrm{SiBj}+$ $\mathrm{SiMk}+\mathrm{BjMk}+\mathrm{SiBjMk}+\sum \mathrm{ijk}$

Yijkl = due to handling/ treatment to $-\mathrm{j}$, handling/ treatment to-k and handling/ treatment to-l to the group to-i, $\mu=$ middle general value, $\mathrm{Si}=$ station influence to- $\mathrm{i}, \mathrm{Bj}=$ Riverbank distance influence ke-j, $\mathrm{Mk}=$ Season Influence to-k, $\sum \mathrm{ijk}=$ error due to treatment/ handling to-j and handling/ treatment to-k on the group to-i, $\mathrm{I}=1,2, \ldots, \mathrm{s}$ ( $\mathrm{s}$ $=$ station $) . \quad \mathrm{J}=1,2, \ldots, \mathrm{b} \quad(\mathrm{b}=$ riverbank distance), $\mathrm{K}=1,2, \ldots, \mathrm{m}$ ( $\mathrm{m}=$ season), with: Factor $\mathrm{s}=$ measurement stations (15 stations), Factor $\mathrm{m}=$ season (Rain \& Dry Season), Factor $\mathrm{b}=$ bank distance $(50 \mathrm{~m}, 100 \mathrm{~m}, 150 \mathrm{~m})$. 
In addition, secondary data in the form of climate data from the WaeRiuapa watershed were obtained from the BMKG StaklimKairatu and the hydrological data of the DAS WaeRiuapa from the Balai Sungai, Maluku Province.

\section{Results and Discussion}

The results of the microbiological quality measurements of the Riuapa river water are presented in Table 4.

\section{Total coliform}

The results of the total coliform analysis between the wet seasaon and dry season varies at all sampling points (Figure 2). The analysis of total coliform in the wet seasaon ranged from 126 counts/ $100 \mathrm{ml}-5000$ counts/ $100 \mathrm{ml}$ and the average total coliform during the wet seasaon was 937.6 counts/ 100ml.The highest coliform count level during the wet seasaon (5000 counts/ 100ml) is found at the sampling location- WR.6, and the lowest coliform count level (126 counts / 100ml) is found at the WR 5 sampling point. While the analysis of total coliform in the dry season ranged from 528 counts/ 100ml - 10000 counts/ $100 \mathrm{ml}$ with an average total coliform level of 2222.7 counts/ $100 \mathrm{ml}$. The highest total coliform level in the dry season (10000 counts/ 100ml) was found at the WR. 6 sampling location, and the lowest total coliform level in the dry season (528 counts/ $100 \mathrm{ml}$ ) was found at the WR. 5 sampling point location. Increased levels of total coliform at WR.6 location is due to livestock activities around the rice fields their manure has the potential to pollute the existing irrigation environment next to it, there are residential areas located at the top (RT Km 9) which mostly use water from the irrigation canal/ channel for bathing and washing. However, it is possible that the irrigation canal is also used as a place to defecate, especially by children who like to play or bathe in this place. While the WR.5 location is also the location of the Animal Husbandry Department UPTD - SBB District.In this place freshwater fish ponds are developed where its final waste is discharged into the Riuapa river and not at the WR.6 irrigation channel location. Chapra's (1997) research in Rijal (2013) state that the coliform bacteria group was one of the indicators indicating the presence of domestic waste contaminants in the waters.

Based on class II quality standards PP No. 82 year 2001, the total coliform required is 5000 counts/ $100 \mathrm{ml}$. The analysis results of the total coliform during the wet seasaon tends to be below the quality standard, except for the WR.6 sampling location (5000 counts/ 100 $\mathrm{ml})$. While for the dry season, total coliform analysis on the side of WR.6 (10000 counts/ $100 \mathrm{ml})$ and WR.7 (6200 counts/ $100 \mathrm{ml}$ ) are above the quality standard threshold while most sampling points of the coliform content are below the quality standard threshold as presented in Table 5 and Figure 2.

\section{Fecal Coliform}

The results of Fecal Coliform analysis for the type of Escherichia coli (E. coli) bacteria varies between the wet and dry seasons (Figure 3). The E. coli content is highest in the wet season and is found in a row at WR.8 station (46 counts/ 100ml), WR.14 (43 counts/ $100 \mathrm{ml}$ ), WR.12 (43 counts/ 100ml) and WR.2 (41 counts/ $100 \mathrm{ml})$ with an average $E$. coli level: wet season of 35.53 counts/ $100 \mathrm{ml}$. While for the dry season the highest E. coli levels were found at WR.13 stations (29 counts/ 100ml) and WR 14 (28 counts/ 100ml) with an average of $E$. coli for the dry season an amount of 20.67 counts/ $100 \mathrm{ml}$. While on the other hand the lowest level of E. coli in the wet season is found at WR.4 station (32 counts/ 100ml), and in the dry season the lowest E. coli levels are found at WR.11 and WR.5 stations with the same level that is equal 
to 15 counts/ $100 \mathrm{ml}$. Based on the comparison results with the quality standard it shows that at all stations the E. coli level has exceeded the maximum threshold both based on class II quality standards PP No. 82 year $2001 \quad(<1$ number / 100ml) and PMK No. 32 year 2017 (free of E. coli) as presented in Figure 4.

Fecal Coliform is part of the total coliform that is able to ferment lactose at a temperature of $44.5^{\circ} \mathrm{C}$. About $97 \%$ of the total content of Coliform bacteria. Human feces are Fecal Coliform, which mainly consists of Escherichia (E. coli) and several Klebsiella species. These fecal coliform bacteria are found also in animal feces (Effendi, 2003). Escherichia coli is one of the harmless total coliforms found in human feces. The abundant presence of $E$. coli in waters illustrates that the waters are contaminated by human waste, which may be accompanied by pathogenic bacteria contamination. Escherichia coli as one the coli example, that in certain circumstances can defeat the body's defense mechanism, it can stay in the bladder (cystitis), pelvis (pyelitis), kidney and liver. These bacteria can also cause diarrhea, septimia, peritonistis, meningitis and other infections (Suriwiria, 2003).

Human feces can produce pathogenic bacteria in the form of Escherichia coli, Shigella sp., Vibrio cholerae, Campylobacter jejuni and Salmonella, and all are members of fecal coliform. These bacteria can cause diarrhea in humans. While Escherichia coli if consumed continuously will in the long term have an impact on ones' health - where diseases will occur such as inflammation of the intestine, diarrhea, infections of the urinary tract and bile ducts (Prayitno, 2009).

The incidence of diarrhea increased at the peak of the wet season. However, in the dry season the incidence of diarrhea persists because river water is still being used by the community even though some needs are met by using water wells. The dominant environmental factor that causes the outbreak of diarrhea, is namely the lack of inadequate clean water facilities and the disposal of feces and waste into the river, resulting in contamination of the fecal coliform bacteria in river water and causing diarrhea outbreaks.

The results of the factorial analysis on the water quality microbiological parameters are the values of total Coliform and E. coli using two analysis factors, namely the influence of Station and Season, for each of the Total Coliform and E. coli variables is presented in Table 5 and Table 6.

Based on the graphics the season and station interactions towards total coliform values showed that for the wet season the total coliform levels at all stations were low and has experienced an increase in the dry season. A very significant increase was seen at WR.6 and WR.15 stations with a very large difference in value compared to other stations.

From the graph it is clear to see that the $E$. coli value is higher in the wet season when compared to the $E$. coli value in the dry season at all stations with a significant decrease, specifically at WR.8 station. The distribution of $E$. coli levels at all stations is quite different in the wet season compared to the dry season which is almost the same value.

The quality of the microbiological properties in the Riuapa river water, which includes the total coliform and $E$. coli, shows a significant difference between the wet season and the dry season. The analysis of the real difference test showed that the microbiological parameters, namely Total Coliform and E. coli overall water samples, had significant differences at all stations between the wet season and dry season. 
Fig.1 Research Location

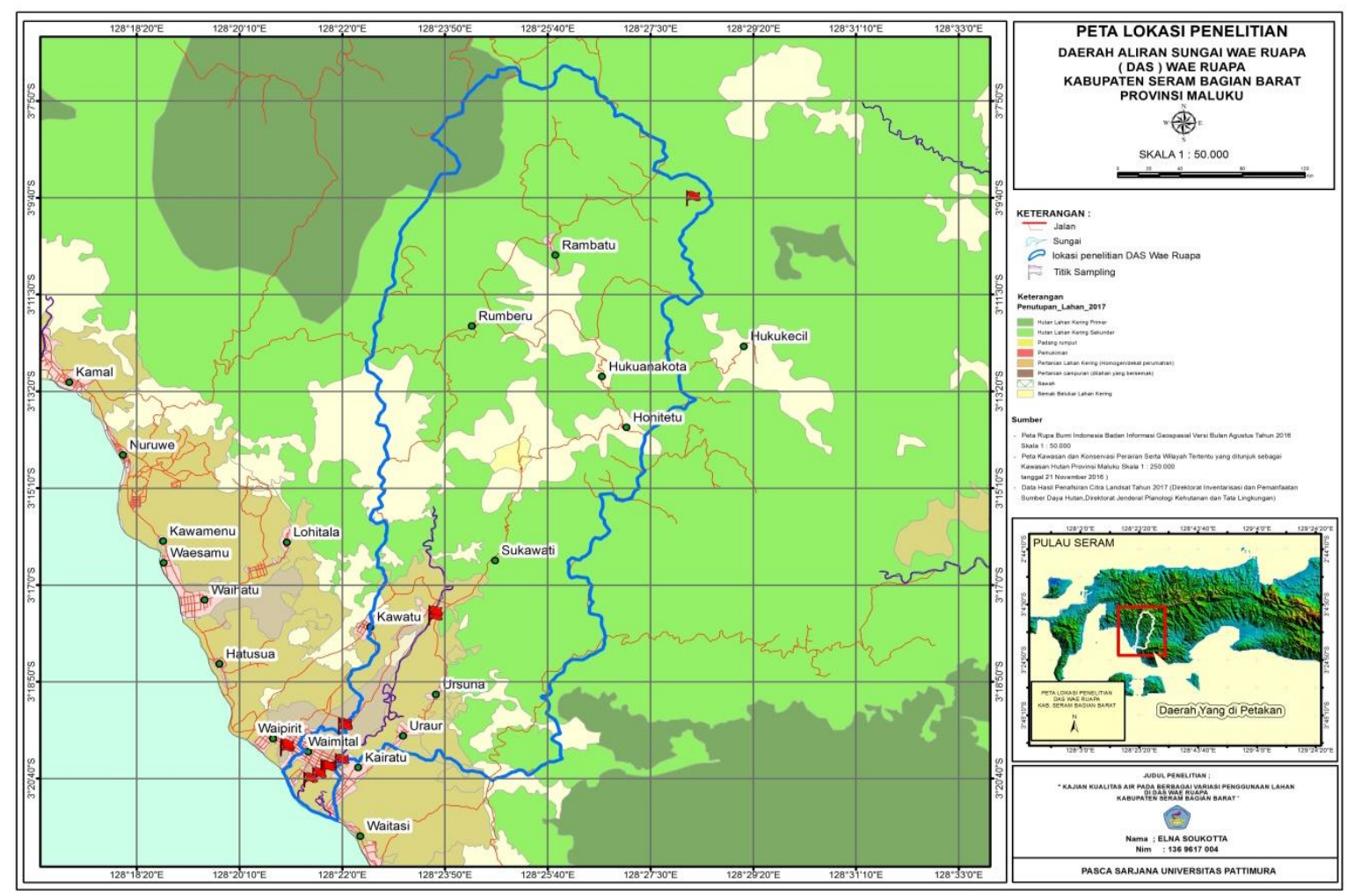

Fig.2 Graphic Plots of Season and Station Interaction Charts towards the Total Coliform Value

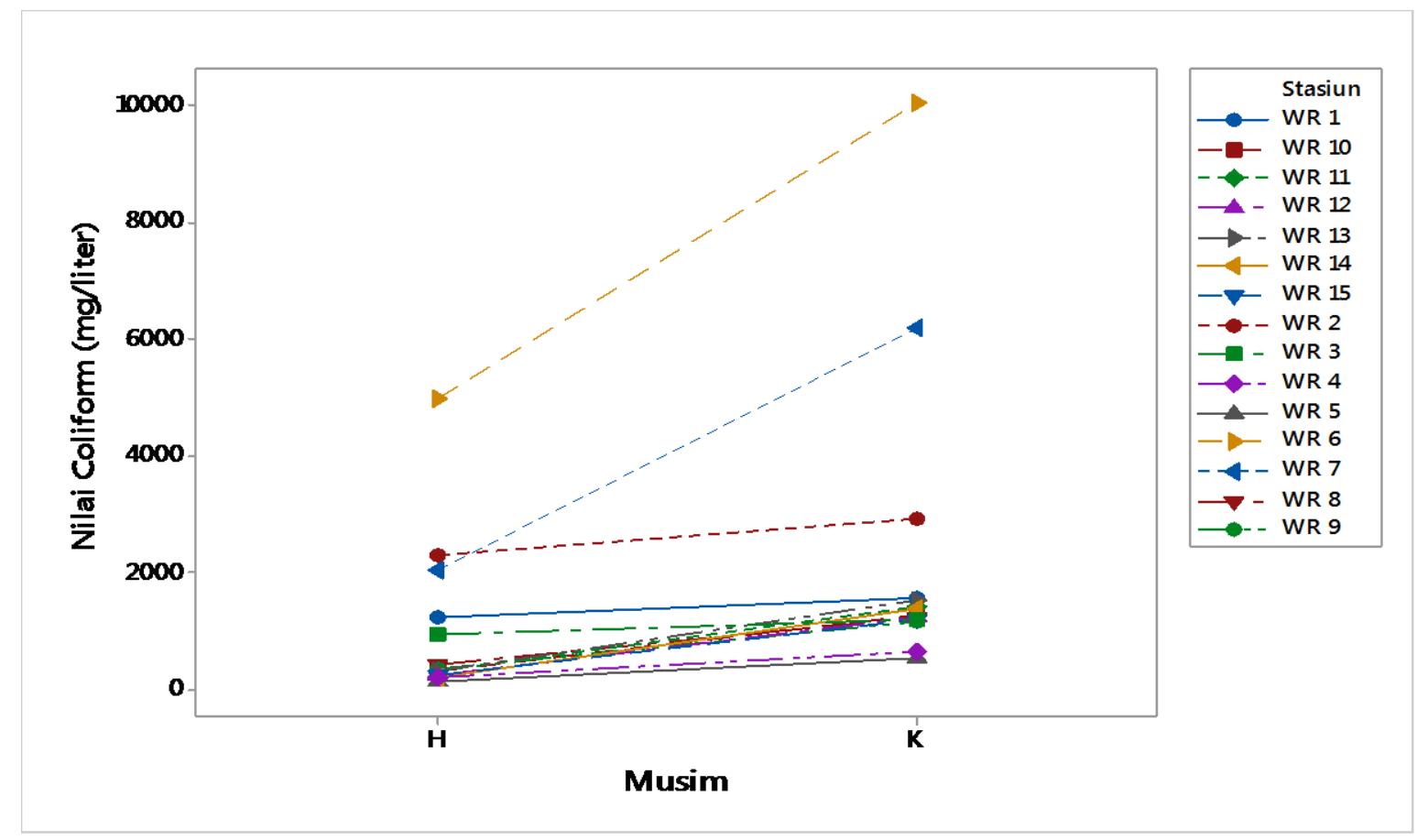


Fig.3 Graphic Plot of Season \& Station Interaction toward the E. coli value

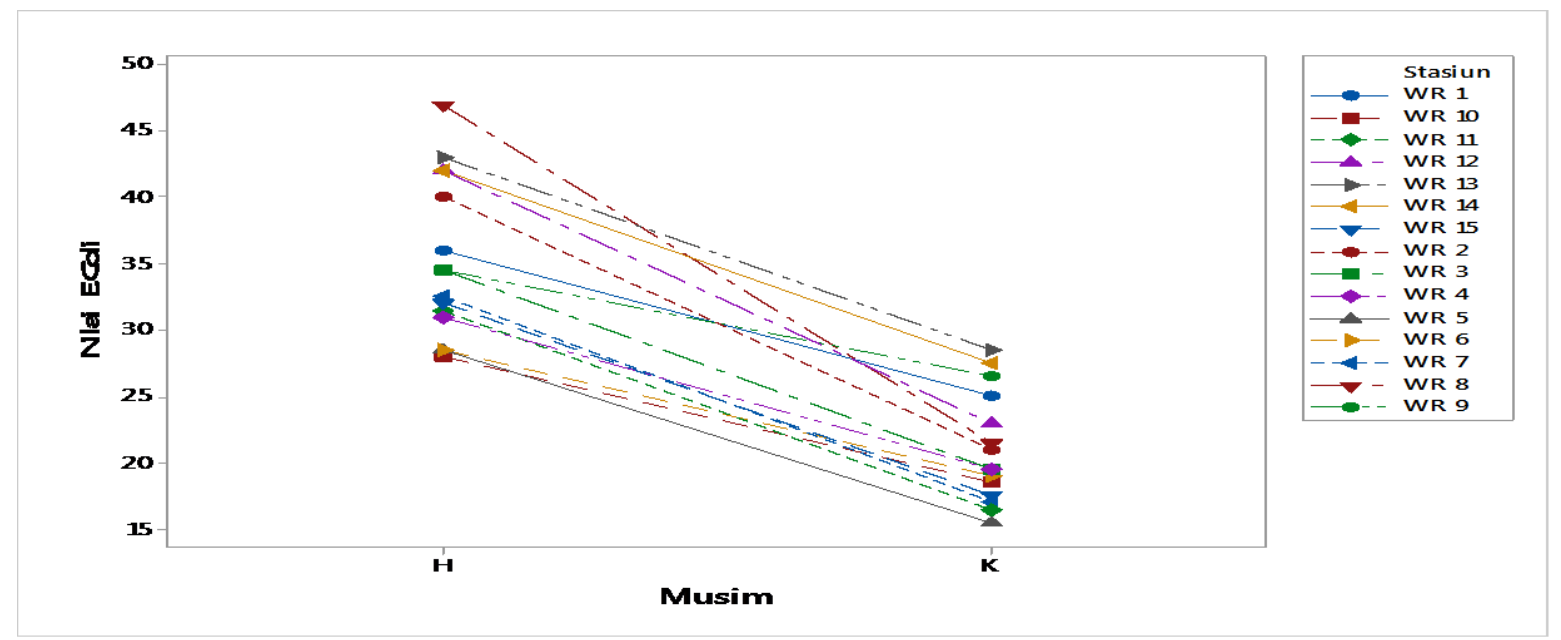

Fig.4 Land Coverage Map of the Wae Riuapa Watershed in 2009 and 2018

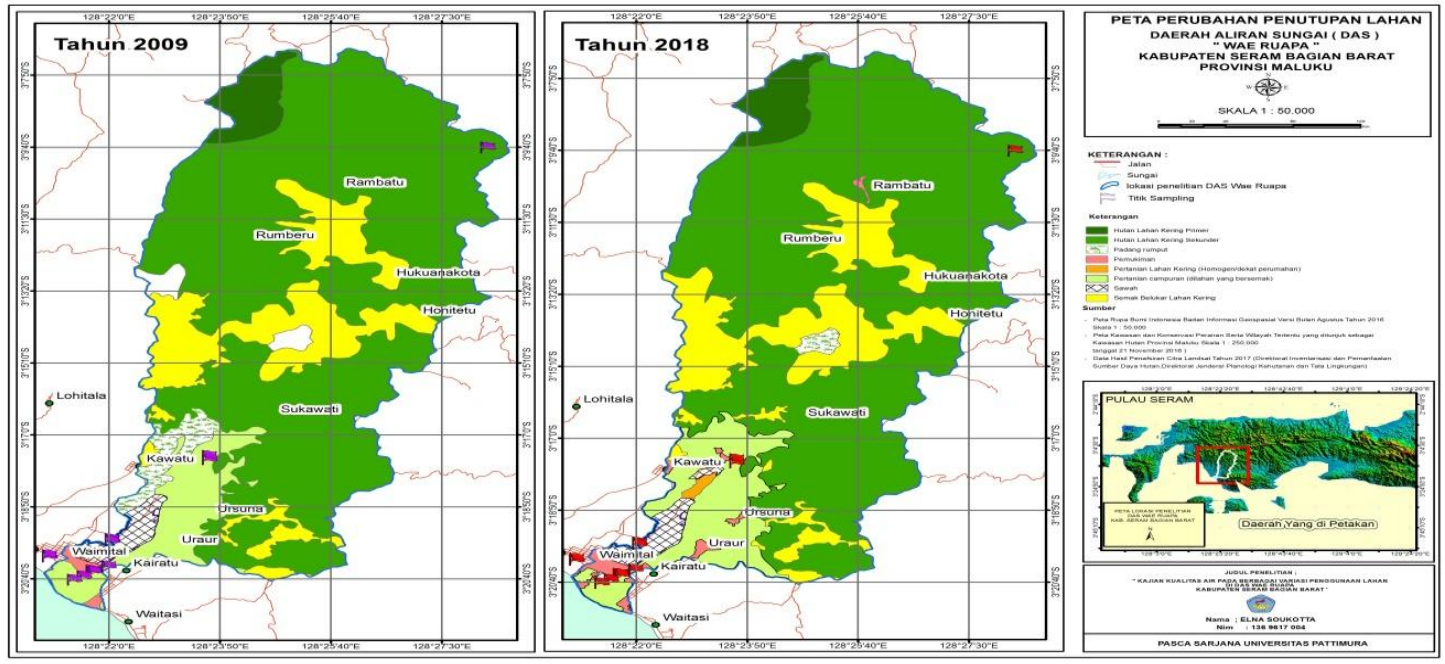

Source: 2018 BPKH Satellite Image Interpretation Results - Region IX of Maluku, 2009 and 2018

Fig.5 Land Coverage Change of the WaeRiuapa watershed - Graphic Year 2009

\section{Land cover area year 2009 (Ha)}

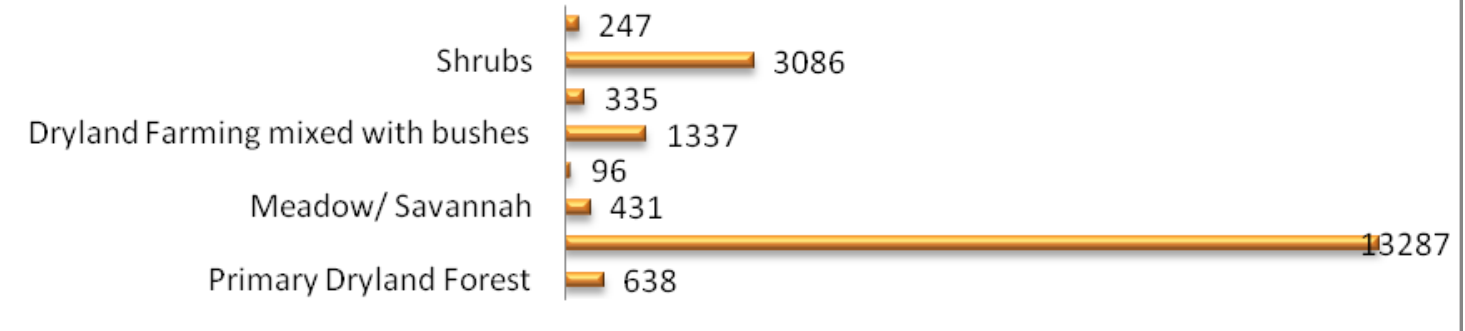


Fig.6 Land Coverage Change of the WaeRiuapa watershed - Graphic Year 2018

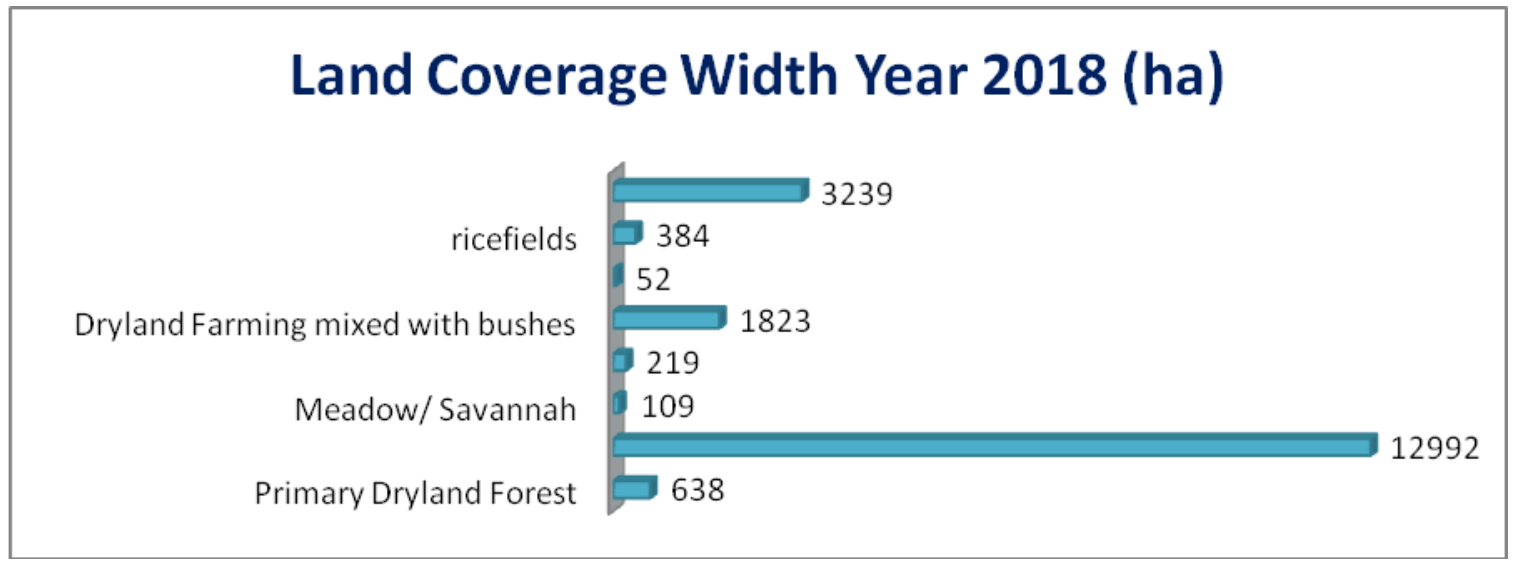

Fig.7 Rainfall Graphic in the WaeRiuapa Watershed - year 2013 - 2018

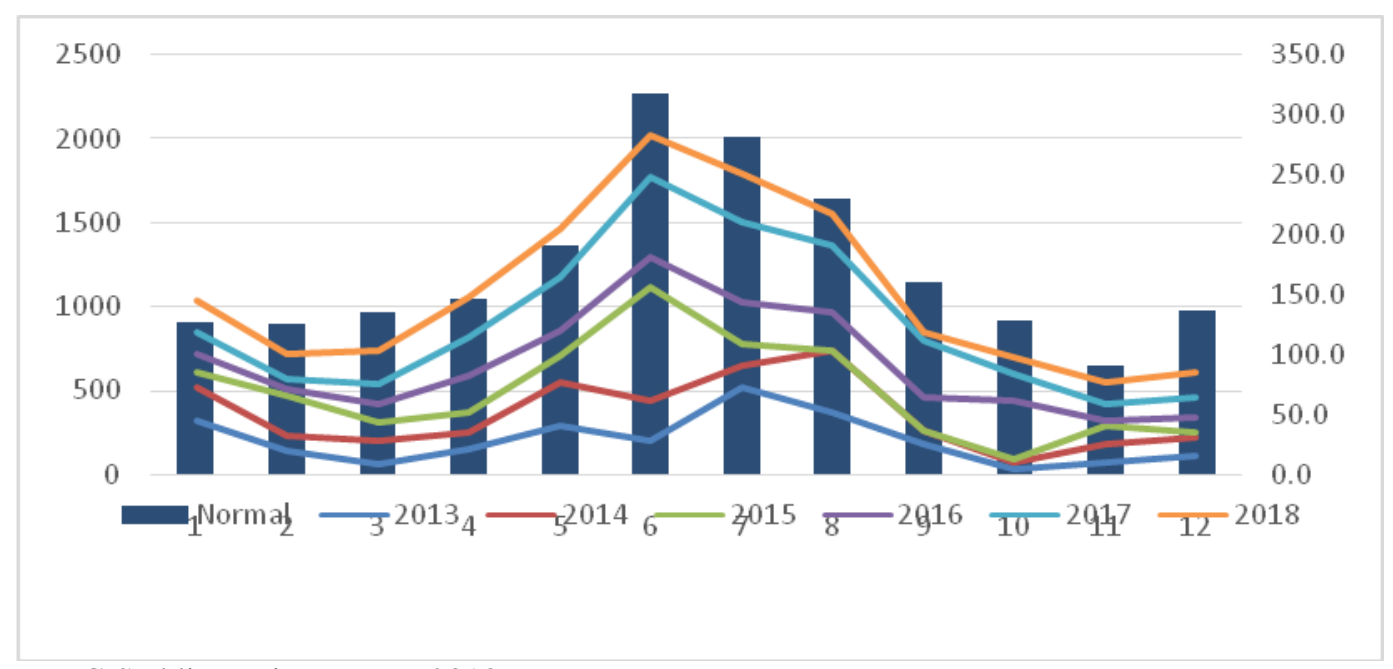

Source: BMKG Staklim Kairatu, Year 2018

Table.1 Class II water quality standard standard

Source: PP No. 82 Year 2001

\begin{tabular}{|c|c|c|}
\hline Parameter & Unit & $\begin{array}{c}\text { Maximum } \\
\text { level }\end{array}$ \\
\hline Total Coliform & CFU/100ml & 50 \\
\hline E. coli & CFU/100ml & $<1$ \\
\hline
\end{tabular}

Table.2 Domestic waste water quality standard

\begin{tabular}{|c|c|c|}
\hline Parameter & Per unit & Maximum Level $*$ \\
\hline Total Coliform & L/ person/ day & 3000 \\
\hline
\end{tabular}

Source: Permenkes No. 32 Year 2017 
Table.3 Water Sampling Location at the WaeRiuapa River Basin, West Seram District

\begin{tabular}{|c|c|c|}
\hline Location Code & Sampling Location & Coordinates \\
\hline WR.1 & Upstream Wai Riuapa 1 & S $03^{0} 17^{\prime} 19,70^{\prime \prime}-\mathrm{E} 128^{0} 23^{\prime} 41,88^{\prime \prime}$ \\
\hline WR.2 & UpstreamWae Riuapa 2 & S $03^{0} 17^{\prime} 21,07^{\prime \prime}-\mathrm{E} 128^{0} 23^{\prime} 41,62^{\prime \prime}$ \\
\hline WR.3 & Dam Area & 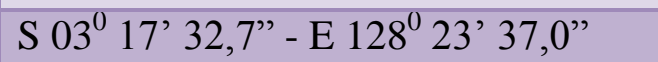 \\
\hline WR.4 & $\begin{array}{l}\text { Dig Wells at Seledri (Celery) } \\
\text { Plantation }\end{array}$ & 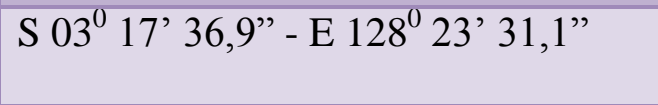 \\
\hline WR.5 & Fish Cultivation Area & $\mathrm{S} 03^{0} 17^{\prime} 38,56^{\prime \prime}-\mathrm{E} 128^{0} 23^{\prime} 25,56^{\prime \prime}$ \\
\hline WR.6 & White Building Irrigation II & $\mathrm{S} 03^{0} 19^{\prime} 35,8^{\prime \prime}-\mathrm{E} 128^{0} 22^{\prime} 09,3^{\prime \prime}$ \\
\hline WR.7 & White Building Irrigation I & 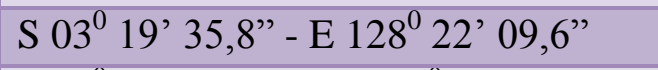 \\
\hline WR.8 & Irrigation Channel - Center 1 & S $03^{0} 19^{\prime} 36,04^{\prime \prime}-\mathrm{E} 128^{0} 22^{\prime} 08,91^{\prime \prime}$ \\
\hline WR.9 & Wai Riuapa - Center 1 & $\mathrm{~S} 03^{\circ} 19^{\prime} 41^{\prime \prime}-\mathrm{E} 128^{\circ} 22^{\prime} 25^{\prime \prime}$ \\
\hline WR.10 & Irrigation Channel - Center 2 & $\mathrm{~S} 03^{0} 20^{\prime} 05,6^{\prime \prime}-\mathrm{E} 128^{0} 20^{\prime} 57,7^{\prime \prime}$ \\
\hline WR.11 & Wai Riuapa - downstream 1 & $\mathrm{~S} 03^{0} 20^{\prime} 21^{\prime \prime}-\mathrm{E} 128^{0} 21^{\prime} 41^{\prime \prime}$ \\
\hline WR.12 & Wai Riuapa - downstream 2 & $\mathrm{~S} 03^{0} 20^{\prime} 23,85^{\prime \prime}-\mathrm{E} 128^{0} 21^{\prime} 51,44^{\prime \prime}$ \\
\hline WR.13 & Wai Riuapa - downstream 3 & $\mathrm{~S} 03^{0} 20^{\prime} 25,14^{\prime \prime}-\mathrm{E} 128^{0} 21^{\prime} 52,00^{\prime \prime}$ \\
\hline WR.14 & $\begin{array}{l}\text { Dig Wells atFam. Bp. } \\
\text { Sukirman }\end{array}$ & $\mathrm{S} 03^{0} 20^{\prime} 26,6^{\prime \prime}-\mathrm{E} 128^{0} 21^{\prime} 41,3^{\prime \prime}$ \\
\hline WR.15 & $\begin{array}{l}\text { Irrigation Channel - } \\
\text { downstream }\end{array}$ & 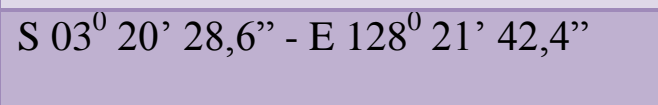 \\
\hline
\end{tabular}

Table.4 Microbiology water quality measurement results of the Riuapa River

\begin{tabular}{|c|c|c|c|c|c|c|c|c|c|c|c|c|c|c|c|c|c|c|c|c|}
\hline \multirow{2}{*}{$\begin{array}{l}\text { Para } \\
\text { meter } \\
\text { Micro } \\
\text { biolog } \\
\text { y }\end{array}$} & \multirow{2}{*}{$\begin{array}{c}\text { Pe } \\
\mathbf{r} \\
\mathbf{U} \\
\text { nit }\end{array}$} & \multirow{2}{*}{$\begin{array}{l}\text { Met } \\
\text { hod }\end{array}$} & \multicolumn{2}{|c|}{ Standard } & \multicolumn{16}{|c|}{ Measurement Result } \\
\hline & & & $\begin{array}{l}\text { PP. } \\
82 / 0 \\
1\end{array}$ & $\begin{array}{l}\text { PMK } \\
.32 / 1 \\
7\end{array}$ & $\begin{array}{l}\text { Seas } \\
\text { on }\end{array}$ & $\begin{array}{l}\text { W } \\
\mathrm{R} \\
1\end{array}$ & $\begin{array}{l}\text { W } \\
\mathrm{R} \\
2\end{array}$ & $\begin{array}{l}\mathrm{W} \\
\mathrm{R} \\
3\end{array}$ & $\begin{array}{l}\text { W } \\
\text { R } \\
4\end{array}$ & $\begin{array}{l}\text { W } \\
\mathrm{R} \\
5\end{array}$ & $\begin{array}{l}\text { W } \\
\text { R6 }\end{array}$ & $\begin{array}{l}\text { WR } \\
7\end{array}$ & $\begin{array}{l}\text { W } \\
\mathrm{R} \\
8\end{array}$ & $\begin{array}{l}\text { W } \\
\text { R } \\
9\end{array}$ & $\begin{array}{l}\text { W } \\
\mathrm{R} 1 \\
0\end{array}$ & $\begin{array}{l}\text { W } \\
\mathrm{R} \\
11\end{array}$ & $\begin{array}{l}\text { W } \\
\mathrm{R} 1 \\
2\end{array}$ & $\begin{array}{l}\text { W } \\
\mathrm{R} 1 \\
3\end{array}$ & $\begin{array}{l}\text { W } \\
\text { R1 } \\
4\end{array}$ & $\begin{array}{l}\mathrm{W} \\
\mathrm{R} 1 \\
5\end{array}$ \\
\hline \multirow[t]{2}{*}{$\begin{array}{l}\text { Total } \\
\text { Colifo } \\
\text { rm }\end{array}$} & \multirow[t]{2}{*}{$\begin{array}{l}\text { Co } \\
\text { un } \\
\text { t/1 } \\
00 \\
\mathrm{ml}\end{array}$} & \multirow[t]{2}{*}{$\begin{array}{c}\text { Dou } \\
\text { ble } \\
\text { tube } \\
\mathrm{s}\end{array}$} & $\begin{array}{l}50 \\
\mathrm{CF} \\
\mathrm{U} /\end{array}$ & 3000 & Wet & $\begin{array}{l}1 \\
2 \\
1 \\
0\end{array}$ & $\begin{array}{l}23 \\
00\end{array}$ & $\begin{array}{r}95 \\
5\end{array}$ & $\begin{array}{r}19 \\
0\end{array}$ & $\begin{array}{r}12 \\
6\end{array}$ & $\begin{array}{l}50 \\
00\end{array}$ & $\begin{array}{r}200 \\
0\end{array}$ & $\begin{array}{r}42 \\
7\end{array}$ & $\begin{array}{r}32 \\
1\end{array}$ & $\begin{array}{r}29 \\
1\end{array}$ & $\begin{array}{r}31 \\
1\end{array}$ & $\begin{array}{r}21 \\
8\end{array}$ & $\begin{array}{r}29 \\
9\end{array}$ & $\begin{array}{r}18 \\
7\end{array}$ & $\begin{array}{r}21 \\
9\end{array}$ \\
\hline & & & $\begin{array}{c}100 \\
\mathrm{ml}\end{array}$ & $\begin{array}{c}\text { ltr/pe } \\
\text { rs./da } \\
\text { y }\end{array}$ & Dry & $\begin{array}{l}1 \\
5 \\
6 \\
6\end{array}$ & $\begin{array}{l}29 \\
00\end{array}$ & $\begin{array}{l}11 \\
76\end{array}$ & $\begin{array}{r}61 \\
9\end{array}$ & $\begin{array}{r}52 \\
8\end{array}$ & $\begin{array}{r}10 \\
00 \\
0\end{array}$ & $\begin{array}{r}620 \\
0\end{array}$ & $\begin{array}{l}12 \\
29\end{array}$ & $\begin{array}{l}11 \\
56\end{array}$ & $\begin{array}{l}12 \\
82\end{array}$ & $\begin{array}{l}13 \\
88\end{array}$ & $\begin{array}{l}12 \\
18\end{array}$ & $\begin{array}{l}15 \\
28\end{array}$ & $\begin{array}{l}13 \\
55\end{array}$ & $\begin{array}{l}11 \\
95\end{array}$ \\
\hline \multirow[t]{2}{*}{$\begin{array}{c}E . \\
\text { coli }\end{array}$} & $\begin{array}{l}\text { Co } \\
\text { un } \\
\text { t/1 }\end{array}$ & $\begin{array}{l}\text { Dou } \\
\text { ble } \\
\text { tube }\end{array}$ & $\begin{array}{l}<1 \\
\mathrm{CF} \\
\mathrm{U} /\end{array}$ & \multirow[t]{2}{*}{$\begin{array}{c}\text { Not } \\
\text { prese } \\
\text { nt }\end{array}$} & Wet & $\begin{array}{l}3 \\
5\end{array}$ & 41 & 33 & 32 & 29 & 29 & 34 & 46 & 35 & 29 & 31 & 43 & 42 & 43 & 31 \\
\hline & $\begin{array}{l}00 \\
\mathrm{ml}\end{array}$ & $\mathrm{s}$ & $\begin{array}{c}100 \\
\mathrm{ml}\end{array}$ & & Dry & $\begin{array}{l}2 \\
4\end{array}$ & 22 & 18 & 19 & 15 & 19 & 16 & 21 & 26 & 17 & 15 & 24 & 29 & 28 & 17 \\
\hline
\end{tabular}

Source: The microbiological characteristic quality analysis in the WaeRiuapa watershed, year 2018 
Table 5. Variance Analysis of Coliform Value

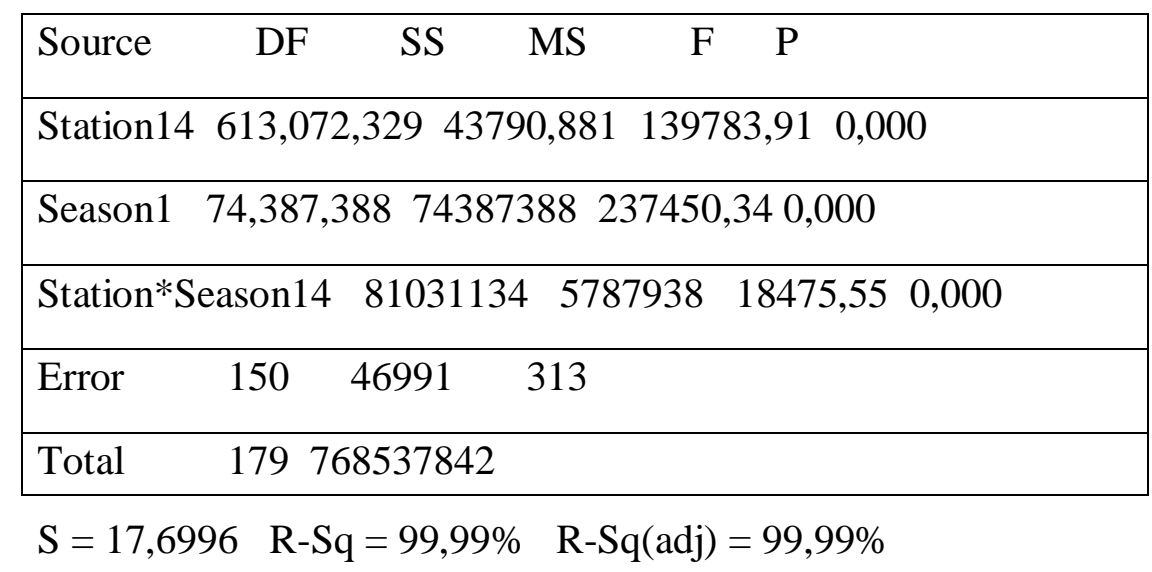

Table6. Variance Analysis of E.Coli Value

\begin{tabular}{lrrrrr}
\hline Source & DF & SS & MS & F & P \\
\hline Station & 14 & 613072329 & 43790881 & 139783,91 & 0,000 \\
\hline Season & 1 & 74387388 & 74387388 & 237450,34 & 0,000 \\
\hline Station*Season & 14 & 81031134 & 5787938 & 18475,55 & 0,000 \\
\hline Error & 150 & 46991 & 313 & & \\
\hline Total & 179 & 768537842 & & & \\
\hline S $=17,6996$ & R-Sq & $=99,99 \%$ & R-Sq (adj) & $=99,99 \%$ & \\
\end{tabular}

The comparison results of the Total Coliform and E. coli variables values with class II quality standards showed that the value of $E$. coli exceeded the standard of quality so the quality of the microbiology of the waters of the Riuapa river did not meet the standards.

The microbiology quality of the well water (Total Coliform) is based on the results of a comparison with the quality standards, as per the Minister of Health Regulation No. 32 of 2017, was found below the standard quality threshold of $3000 \mathrm{l} /$ person/ day with content ranging from $190 \mathrm{l} /$ pers. / day and $619 \mathrm{l} /$ pers./ day at the celery plantation wells and $187 \mathrm{l} /$ pers./ day and 1.3551 / person/ day at the Fam. Sukirman 's water-well. These results indicate that micro-biologically, it is not advisable nor recommended to use this source for drinking water due to the presence of Total Coliform content in the water-well even though it is still below the quality standard threshold.

The results of the microbiological well-water quality (E. coli) comparison are based on the quality standards of Permenkes No. 32 year 2017, is above the required standard threshold, meaning it is free of E. coli, both types of well water already contain $E$. coli making it not suitable as and for drinking water.Significantly the levels of pollutants in the water are influenced by season and station location, and significant changes starting upstream to downstream are found. During the rainy season, pollutant levels increased at stations in the middle and downstream segments of the Riuapariver. In this segment 
there is human activity and is an area of agriculture (rice fields) and dominant settlements that contribute a lot of waste disposal into nature. In general, based on PP 82 the water quality of the Riuapa river has an impact on the environment.

In year 2001 regarding class II water quality standards (for river water) and Permenkes 32 year 2017 (for well-water) it is proven that the levels of pollutant parameters in the river water and well-water are still quite high and will in the run affect the population's health who consumed them.

The variables of Total Coliform and E. coli are indicators of healthy drinking water. The number of these organic compounds can be related to community activities that take place along and around the watershed. Based on observations, at stations that have high levels of $E$. coli and total coliform, there are indeed organic and inorganic wastes household waste. Statements of some of the residents who live and interact in the vicinity of the downstream irrigation, they experienced itching when exposed to or using the water from the channel and during the wet season the people of Waimital village were often experiencing vomiting \& diarrhea illnesses This indicates that there is considerable pollution in the downstream irrigation channel due to community waste production which is directly discharged into the canal. Based on observations of several rice fields, tofu industries (home industries), lodging, residents' houses and food stalls directly adjacent to waterways, it turns out that they dispose their waste directly into the canal. This is thought to be one of the causes of itching and diarrhea/ vomiting sickness in the community.

Changes in land cover over the Wae Riuapa watershed affect the amount and water debit of the Riuapa river. The results showed that the water debit and the water level of the Riuapa river were also affected in August 2018 the water level of the Riuapa river was very high with a water flow reaching $0,1.06 .13 \mathrm{~m} / \mathrm{sec}$ then gradually decreasing until December where the Riuapa river is $03.01 .48 \mathrm{~m} / \mathrm{sec}$ with a water level only reaching the range between $25 \mathrm{~cm}$ (in the upstream area) and the water debit $01.39 .06 \mathrm{~m}$ / sec with a water level reaching $35 \mathrm{~cm}$ downstream. This indicates that the increase in the debit of the river water has an impact on the dilution and dissolution of the ions contained in the soil. This can be seen in the test parameters' value where in the wet season, the content of Total Coliform and $E$. coli increases at several points, as follows: WR.6 (Total Coliform $5000 \mathrm{jml} / 100 \mathrm{ml}$ ), WR.8 (E. coli 46 jml/100ml), WR.12 (E. coli $43 \mathrm{jml} / 100 \mathrm{ml}$ ), and WR 14 (E. coli $43 \mathrm{jml} / 100 \mathrm{ml}$ ) while in the dry season the Total Coliform levels increased at WR.6 $(10,000 \mathrm{ml} / 100 \mathrm{ml})$ stations representing the upstream segment (WR.6), Middle segment (WR.8) and downstream segments of the Riuapa river (WR.12 and WR.14).

This is in line with the results of Suryo et al., (2014), stating that the factors influencing the water quality are due to human activities and nature processes, because the upstream to downstream segments show a dominant change in land use, which in turn increases the level of pollution and pollutant content that varies according to the type of land use implemented.

The land cover change map of the WaeRiuapa watershed (Picture 4) shows that land cover changes have occurred over the past 10 years. Some types of land use have increased widely in 2018 including secondary dry-land forests, settlements, dry land agriculture mixed with shrubs, rice fields and shrubs whereas for meadow areas and open land there has been a widespread decline in 2018 (Figure 5 and 6). 
The change in the land coverage rate at the WaeRiuapa watershed is shown on the Figures 5 and 6.

Changes in land cover over the WaeRiuapa watershed also affect rainfall fluctuations and river water debit. Based on the rainfall graphics over the last six years in the WaeRiuapa watershed shows that the amount of rainfall is in the normal range with a steadily increasing rainfall from year to year nearing the normal limit. More specifically in 2018, rainfall in January, April and May has exceed the normal limit and in August the amount of rainfall is close to normal. While the amount of rainfall in December is below the amount of normal rainfall as shown in Figure 7.

In conclusion, the results of the water microbiology quality analysis are above the threshold of good quality standards based on class II PP water quality standards no. 82 year 2001 (for river water) and Minister of Health Regulation No. 32 of 2017 (for well-water) this shows that the level of pollutant parameters in the river water and well-water are still quite high, namely $E$. coli average in the wet season is 35.53 counts/ $100 \mathrm{ml}$, during the dry season an average of 20.67 counts/ 100ml. (BM E. coli: $<1$ account/ 100ml) and Total Coliform average in the wet season is 937.6 counts/ $100 \mathrm{ml}$, and during the dry season an amount an average of 2222.7 counts/ 100ml (bm Total Coliform: 3,000 counts/ $100 \mathrm{ml}$ ), an amount like this will affect the population's health through consumption.

Changes in land cover resulted in an increase in the river water debit affecting the process of dilution and dissolution of ions contained in the soil, this can be seen in the value of the test parameters where the content of Total Coliform variable increased 5,000 counts/ $100 \mathrm{ml}$ to 10,000 counts $/ 100 \mathrm{ml}$ specifically at WR.6 stations in and during the wet and dry seasons.
*Notes: E. colixJumlah/ 100ml = counts/ colony/ number of - not sure which one to use. In this case the word "counts" has been used.

\section{References}

Asdak, C. 2010. Hidrologi dan Pengelolaan Daerah Aliran Sungai. Hydrology and Management of Watersheds Gajahmada University Press. Yogyakarta.

Effendy, H. 2003. Telaah Kualitas Air bagi Pengelolaan Sumber Daya dan Lingkungan Perairan. Penerbit kanasius. Yogyakarta. A Water Quality Review for the Resources and Marine Environment Management. Publisher Kanasius, Yogyakarta.

Muhammad Rijal, 2013. Kualitas Air Sungai Arbes Ambon Berdasarkan Nilai Koliform Fecal. Program Studi Pendidikan Biologi.IAIN AMBON. "Arbes" River Water Quality Ambon Based on Coliform Fecal Value. Biology Education Study Program, IAIN AMBON

Republik Indonesia. 2001. Peraturan Pemerintah Nomor 82 Tahun 2001 tentang Pengelolaan Kualitas Air dan Pengendalian Pencemaran Air. Jakarta: Sekretariat Negara. Government Regulation Number 82 year 2001 Regarding the Water Quality and Water Pollution Control Management. Jakarta: State Secretariat.

Republik Indonesia. 2017. Peraturan Menteri Kesehatan Nomor 32 Tahun 2017 tentang Standar Baku Mutu Lingkungan dan Persyaratan Kesehatan Air Keperluan Sanitasi, Kolam Renang, Solus per Aqua. Minister of Health Regulation Number 32 Year 2017 regarding

Suriawiria.U, 2003, Mikrobiologi Air dan Dasar-Dasar Pengolahan Buangan Secara Biologis, PT. ALUMNI, Bandung. Water Microbiology and Basics of Biological Waste 
Management, PT. ALUMNI, Bandung. Suryo Ari W, Winardi Dwi Nugraha, Endro Sutrisno. 2014. Analisis Kualitas Air Sungai Bringin Kota Semarang Dengan
Metode Nsf - Ika (Studi Kasus Sungai Bringin). Kajian Kualitas Air. 2014.

\section{How to cite this article:}

Soukotta Elna, Oszaer Robert, Bokiraya Latuamury. 2019. The Microbiology Quality Analysis of the Waters of Riuapa River and Its Impact on the Environment. Int.J.Curr.Microbiol.App.Sci. 8(07): 11-22. doi: https://doi.org/10.20546/ijcmas.2019.807.003 